\title{
融雪に伴う浸透流がコムケ湖の 干潟水質に及ぼす影響
}

\author{
竹内 友彦 ${ }^{1}$ 駒井 克昭 ${ }^{2} \cdot$ 中山 恵介 ${ }^{3} \cdot$ 渡辺 謙太 ${ }^{4} \cdot$ 一見 和彦 5 \\ 佐藤 $之^{2}$ 信 ${ }^{6}$ 桑江 朝比呂 $^{7}$ \\ ${ }^{1}$ 学生会員 北見工業大学大学院 社会環境工学専攻（ $\bar{T} 090-8507$ 北海道北見市公園町165） \\ E-mail: m1552200084@std.kitami-it.ac.jp \\ ${ }^{2}$ 正会員 北見工業大学准教授 工学部社会環境工学科（同上） \\ 3正会員 北見工業大学教授 工学部社会環境工学科（同上） \\ 4港湾空港技術研究所 沿岸環境研究領域沿岸環境研究チーム研究官 \\ （干239-0826神奈川県横須賀市長瀬3-1-1） \\ 5香川大学瀬戸内圈研究センター（†761-0130香川県高松市庵治町鎌野4511-15） \\ 6正会員＼cjkstart株式会社豊水設計（广065-0033北海道札幌市東区北33条東16丁目2-2） \\ 7正会員 港湾空港技術研究所 沿岸環境研究領域沿岸環境研究チームリーダー
}

（三239-0826神奈川県横須賀市長瀬3-1-1）

\begin{abstract}
北海道北東部に位置するコムケ湖において，融雪期〜夏期における干潟域での塩分や水位，干潟近辺の 陸域地下水位のモニタリングと干潟域における浸透流の数值解析を行った. 現地観測の結果, 陸域地下水 位と干潟における水位は, 融雪期において相対的に陸側の地下水位が高いことが明らかになった。 さらに 数值解析の結果から，陸域地下水位が高い場合では地下水位が低い場合と比べ，より広範囲にわたり塩分 の上昇が妨げられていることが示された。 また, 地下水位が高い場合にはわずかに湧出が強く, 干潟域で 低塩分化していることが示された．春季において干潟域付近の塩分濃度が低く保たれることで低塩分帯に 生息する水生生物が生息できる環境が生まれ，これらを餌とする多くの鳥類が春季にこの干潟域付近で観 測される要因となっていることが示唆された.
\end{abstract}

Key Words : groundwater level, seepage flow, tidal flats, snow melting, salinity

\section{1. はじめに}

コムケ湖は，北海道北東部に位置する自然干潟が形成 されている汽水湖でありシギやチドリ，冬季にはオジロ ワシなど年間 170 180 種の野鳥が飛来している ${ }^{1,2,2,3), 4)}$. また，その約 9 割が渡り鳥であることから ${ }^{5)}$ ，わが国に 飛来する渡り鳥と干潟の生態系を考える上で重要な湖沼

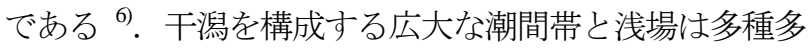
様な生物の生息空間であり, 生態学的に重要な場所であ ると同時に，著しい水質浄化機能を有していることが知 られている 7,8),9) .干潟域における生物の生息に適した 環境や，その形成要因を明らかにすることは，将来にわ たり失われた干潟域の再生や現存する干潟域の保全にお いて重要である ${ }^{10)}$.

過去の研究において, コムケ湖の豊かな干潟環境は, 海と直接つながっている第 1 湖に対して, 淡水を安定し て供給する第 2 湖と第 3 湖の淡水・塩水の供給バランス により成り立っていることが示されている ${ }^{11)} .3$ 次元数
值計算モデルを利用することで，第 1 湖および第 2 湖に おける特殊な淡水・塩水の供給バランスが融雪期と夏期 において発生していることも示されている ${ }^{12)}$.また，融 雪期において第一湖の干潟域付近では塩分濃度が低く保 たれることで，低塩分帯に生息する水生生物が生息しや すい環境が生まれると言われており，さらに第一湖の干 潟域付近では融雪期に数多くの野鳥が観察されることが 分かっている ${ }^{12,13)}$. 一方で, 干潟における環境研究とし て，融雪期における地下水の供給が重要な役割を果たし ていることが示されており, 干潟内部における流動の重 要性が指摘されている ${ }^{14}$. ᄂ しかし, 過去の研究において 地下水供給のメカニズムは未解明のままであり，さらに 干潟水質との直接的な関係は十分解明されていない，そ こで本研究は，コムケ湖における干潟域での融雪期〜夏 期における干潟水質と合わせて，干潟近辺での陸域地下 水位のモニタリングと干潟域における浸透流の数值解析 を実施し，季節的な陸域地下水位の変化が干潟水質に及 ぼす影響を明らかにすることを目的とした。 


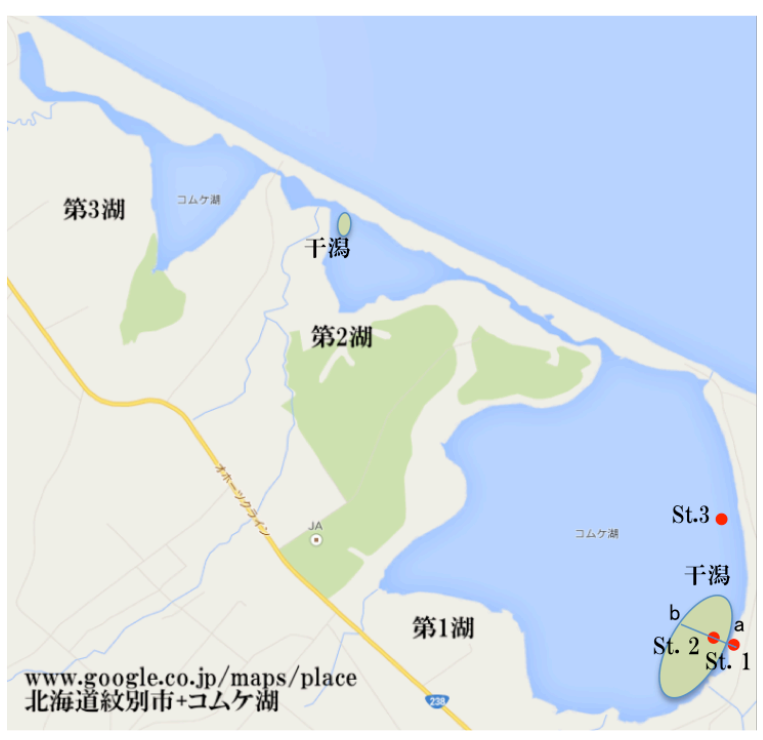

図-1 コムケ湖における観測地点

\section{2. 研究手法}

\section{（1）コムケ湖の干潟域における現地観測}

コムケ湖は 3 つの水域からなる湖であり, 第 1 湖の湖 口によってオホーツク海と接続し，潮汐に伴う海水の出 入りにより湖内に干潟が形成されている. 図-1 はコムケ 湖の地図と観測地点を表しており，図-2 は図-1 中の観 測点 St. 1 およびSt. 2 を含む第 1 湖干潟域における鉛直 断面を示している. St. 2 は地形勾配約 1/700 から 1/600 の満潮汀線付近に位置している.

第 1 湖の干潟域における水質と陸域の地下水位の関係 を明らかにするため，干潟域地中の塩分，水温と陸域の 地下水位を連続観測した。 観測期間は融雪期〜夏期にわ たる 2014 年 5 月 8 日から 2014 年 7 月 10 日までである. 測定位置は St. 2 が干潟面上 $+5 \mathrm{~cm}$, 干潟面下-20, -30 , お よび-40 cm の深さである. また, 測定間隔は 10 分であ る. 測定に用いた機器はメモリ式水温塩分計(Compact CT, JFE Advantec Co.,Ltd.)である. また St. 2 では干潟面-30 cm に圧力計(SERA Diver, Eijkelkamp)も設置した．湖水位に 関しては St. 3 において水位濁度計(Infinity-Turbi, JFE Advantec Co.,Ltd.)を用いて測定した. さらに，St. 1 にお いて陸域地下水位の観測のため内径約 $10 \mathrm{~cm}$ の井戸を掘 削し，圧力計を用いて孔内の地下水位を測定した。 寸心゙ ての水位は圧力計のデータを気圧補正することで求めた. 気圧や降水量は, 気象庁の紋別観測所のデータを 10 分毎 に線形補間したデータを使用した。

\section{（2）干潟域地中の浸透流と塩分分布の数值解析}

融雪に伴う浸透流の変化が，干潟水質に及ぼす影響の メカニズムを解明するため, 鉛直 2 次元の数值解析を行

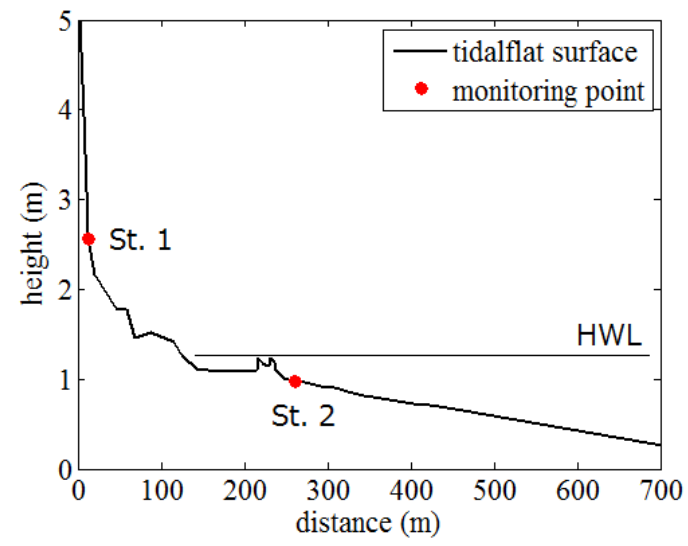

図-2 第 1 湖干潟域の鋁直断面

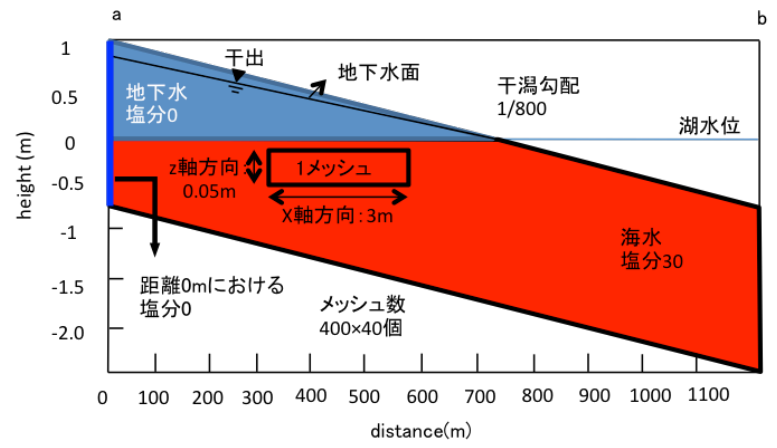

図-3 数值計算初期条件

った．数值解析では，融雪期〜夏期における陸域の地下 水位の高さの変化が地中の鉛直流速分布と塩分分布に及 ぼす影響について考察することを目的とする。

\section{a) 基礎式}

地中での浸透流の $x$ 軸方向流速 $u$ はダルシー則を用い て求めた。

$$
u=i k
$$

ここで $u: x$ 軸方向流速， $i:$ 動水勾配， $k$ : 透水係数であ る。なお，本解析では不飽和の場合であっても飽和の透 水係数を使用した．さらに，動水勾配は湖水位によって 変化するが, 計算結果で得られる水分量から推定したも のではなく，理解しやすくするため理想的な状態を与え ている. 動水勾配は $x$ 軸方向で隣同士のメッシュの塩分 濃度の影響を考慮した静水圧の差から求めた。

$z$ 軸方向の流速 $w$ は連続式を用いて算出した.

$$
\frac{\partial u}{\partial x}+\frac{\partial w}{\partial z}=0
$$

ここで， $w: \mathrm{z}$ 軸方向流速である.

さらに，干潟域地中の水分量と塩分を計算するため, 移流拡散方程式を用いた。

水分量に関する移流拡散方程式：

$$
\frac{\partial \theta}{\partial t}+u \frac{\partial \theta}{\partial x}+w \frac{\partial \theta}{\partial z}=D_{H} \frac{\partial^{2} \theta}{\partial x^{2}}+D_{V} \frac{\partial^{2} \theta}{\partial z^{2}}
$$




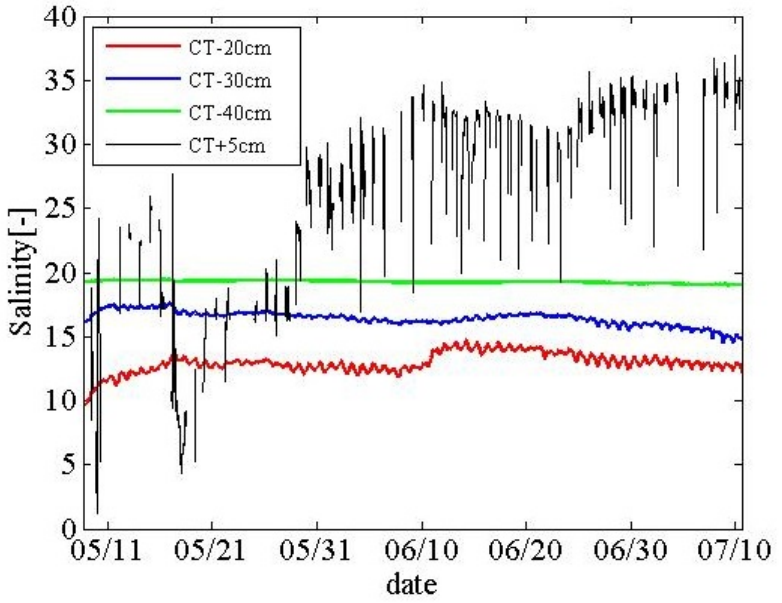

図-4 St. 2 における塩分の経時変化

塩分に関する移流拡散方程式：

$$
\frac{\partial s}{\partial t}+u \frac{\partial s}{\partial x}+w \frac{\partial s}{\partial z}=D_{H} \frac{\partial^{2} s}{\partial x^{2}}+D_{V} \frac{\partial^{2} s}{\partial z^{2}}
$$

ここで， $\theta$ : 水分量, $t$ : 時間, $D_{H}$ : 水平拡散係数, $D_{V}$ : 鉛直拡散係数, $s$ :塩分である. 最大空隙率は $30 \%$ とした. なお，本モデルでは圧力水頭の算出時に密度分布も考慮 されており, 密度流の効果も考慮されたモデルとなって いる.

\section{b) 計算条件}

図-3 は計算領域と計算条件の模式図を示している. 計 算領域は第 1 湖の干潟域における断面 a-b（図-1）であ り，干潟域の地形勾配を 1/800 とした。 干潟域は沿岸方 向に $500 \mathrm{~m}$ 以上の規模を有しており，浸透流による現象 が沿岸方向に一様であると考えられるため，岸沖方向之 深さ方向の鉛直 2 次元の現象を対象として解析を行った. メッシュサイズは $x$ 軸方向 $3 \mathrm{~m}, z$ 軸方向 $0.05 \mathrm{~m}$ とし, メッシュ数を $400 \times 40$ 個とした. 過去の駒井らの研究か $\zeta^{14)}$, St.2 での鉛直方向透水係数 $K_{V}$ は $3.97 \mathrm{E}-6 \mathrm{~m} / \mathrm{s}$ であ り，水平方向透水係数 $K_{H}$ は $1000 * d x / d z^{*} K_{V}$ より, 0.2382 $\mathrm{m} / \mathrm{s}$ とした。 これらの值を用い, 鉛直拡散係数 $D_{V}$ を $0.0025 * K_{V} / 2.0$ より $4.9625 \mathrm{E}-9 \mathrm{~m}^{2} / \mathrm{s}$, 水平拡散係数 $D_{H}$ を $0.0025 \mathrm{E}-8 * K_{H} / 2.0$ より， $2.9775 \mathrm{E}-12 \mathrm{~m}^{2} / \mathrm{s}$ とした. 計算期 間は 90 日間とし，計算時間間隔は $1 \mathrm{~s}$ とした. 初期值と して, 陸側からの地下水浸透流の塩分を 0 , 海水の塩分 を30 とした. さらに, 境界条件として水平方向と鉛直方 向の水の出入りはないものとし, 平均の湖水位を $\mathrm{z}=0.0$ $\mathrm{m}$ とした. 湖水位以下の干潟地中は寸べて海水で満たさ れているとし, $\mathrm{z}=0.0 \mathrm{~m}$ 以上の干潟地中の塩分を 0 とし, $\mathrm{z}=0.0 \mathrm{~m}$ 以下の干潟地中の塩分を 30 とした. また, 陸域 地下水位の高低差による干潟水質一の影響を検討寸るた め, 陸域地下水位を $0.8 \mathrm{~m}, 1.1 \mathrm{~m}, 1.6 \mathrm{~m}$ の 3 つのケース について解析を行った．現地の湖水位変動に合わせて計 算では湖水位変動を $70 \mathrm{~cm}$ として与えた. さらに計算開
始時の湖水位は $\mathrm{z}=0.0 \mathrm{~m}$ とし, 湖水位変動の周期は 12 時間とした.

\section{3. 観測結果}

\section{（1）干潟域地中における塩分の経時変化}

図-4 に St. 2 における塩分の経時変化を示寸. ここで は，水位から干潟面上 $+5 \mathrm{~cm}$ （図-4 中，黒線）に設置し た EC 計が干出したと判断される時間帯のデータは削除 した. 塩分の経時変化より, 干潟面から-20 cm (図-4 中, 赤線), $-30 \mathrm{~cm}$ (図-4 中，青線）において塩分は約半日 周期で変動しているのに対し， $-40 \mathrm{~cm}$ (図-4 中, 緑線) での塩分にはその変動が見られずほぼ一定の值を示して いる. これは- $20 \mathrm{~cm},-30 \mathrm{~cm}$ の地下水位が， $\mathrm{M}_{2}$ 分潮によ って第 1 湖内部まで入り込んだ海水の影響を受けていた と考えられる. さらに，干潟表層の測定值である $+5 \mathrm{~cm}$ の值を見ると, 融雪期に塩分がおよそ 25 程度なのに対し， 夏期に近づくにつれて塩分は 30〜35 と高い值を示して いることが分かる．これは融雪期において，増加した河 川水や地下水といった淡水の影響を受けたものと思われ る. 夏期になり融雪に伴う多量の出水が無くなると, 潮 汐によって第一湖内部まで入り込んでくる海水の影響を 強く受けたと思われる.

\section{(2) 干潟域地中における密度と水温の経時変化}

図-5, 図-6 に St. 2 における密度と水温の経時変化を 示す. 数日以上の長周期の密度変化は各深さでそれぞれ 同様に推移している．しかし，より干潟面上に近くなる につれて半日周期の変動幅が大きくなっていることがわ かる (図-5). 密度の值の変化は塩分の高低に左右され るため, 半日周期の変動が大きい $-20 \mathrm{~cm}$ は先ほど述べた 潮汐による海水流入の影響を強く受けていると思われる.

St. 2 における水温の経時変化（図-6）より，塩分，密 度と同㥞に，より干潟面上に近い EC 計の值がその他の 深さに比べて大きく変動していることが分かる．これは 日射の影響と考えられる. 水温の值の変動にはおよそ半 日周期の変動が見られ，日射があると思われる日中の水 温の測定值が高いことが分かった．また，季節的な気温 の上昇や日射時間の増加等の要因により, 夏期になるに つれて水温は全体的に高い值を示していることが分かる.

\section{（3）季節的な陸域地下水位の変化}

図-7 は陸域の地下水位(St. 1) と干潟(St. 2)における水 位の測定結果を示す．測定結果から，融雪期において相 対的に陸域地下水位は高く, 徐々に減少していることが 分かる.こうした融雪期に陸域地下水位が高いことが, 


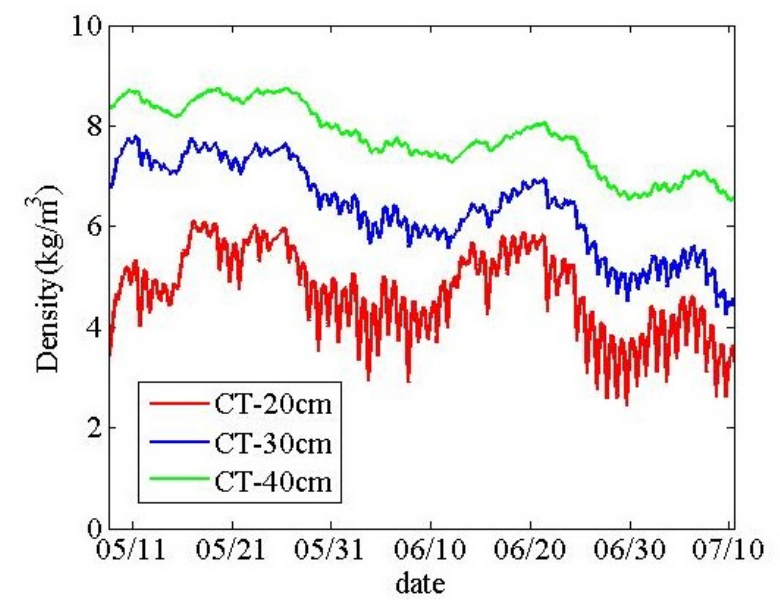

図-5 St. 2 における密度の経時変化

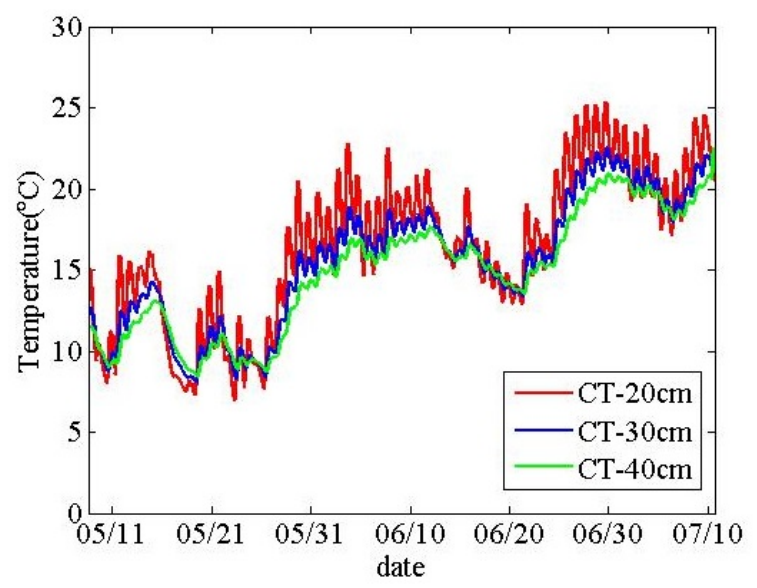

図-6 St. 2 における水温の経時変化

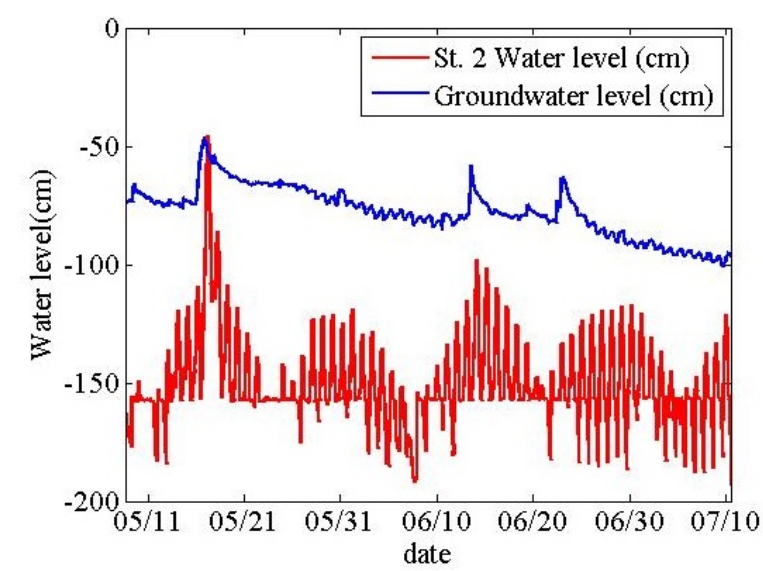

図-7 観測井戸における地下水位と St. 2 における水位

干潟域に影響を及ぼしていると推測された．既往の研究 において，融雪期における地下水湧出が干潟域での塩分 を低く保ち，低塩分帯に生息する水生生物が生息しやす い環境が生まれる可能性が示されており ${ }^{12)}$, St. 2 付近の 干潟域では，実際に春季において地下水浸透流の湧出方 向にある ${ }^{14}$. 融雪期において St. 2 付近の干潟域ではこれ らの水生生物を餌とする数多くの渡り鳥など鳥類が観察 される要因になっていることが推測されている.
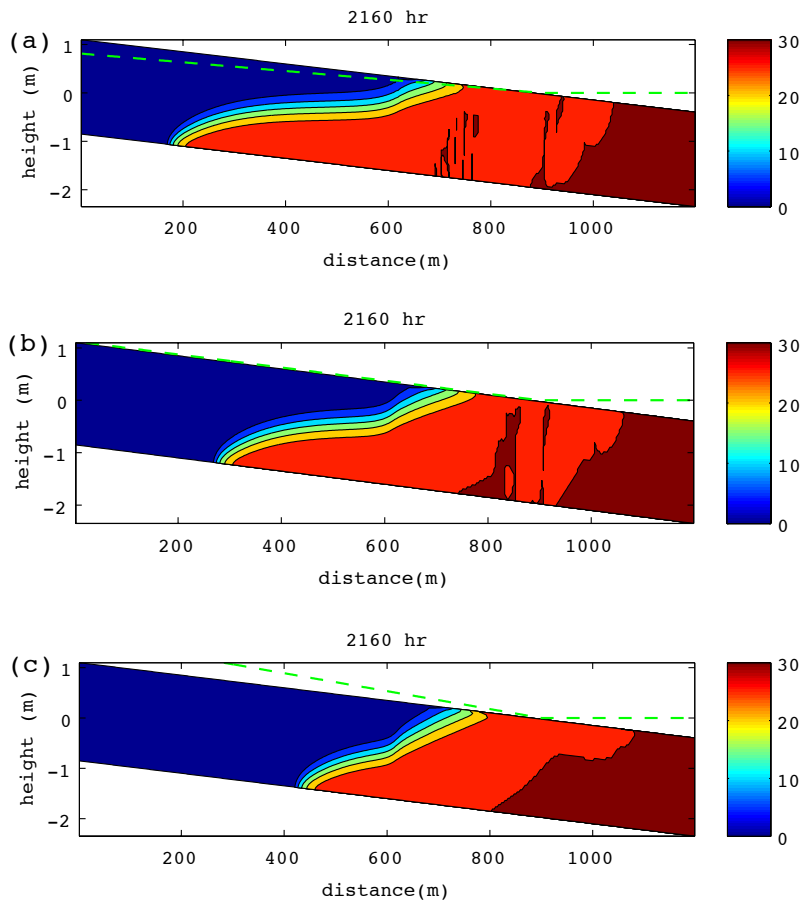

図-8 陸域地下水位による塩分分布の変化. (a)地下水位 $0.8 \mathrm{~m}$ (干潟表面で不飽和状態)，(b)地下水位 $1.1 \mathrm{~m}$ （干潟表面 まで飽和状態)，(c)地下水位 $1.6 \mathrm{~m}$ （干潟表面に水圧がか かった被圧の状態)

\section{（4）数値解析による陸域地下水位の変化が干潟域に及 ぼす影響の考察}

図-8 に計算期間 90 日間終了時における, 干潟断面 a-b の陸域地下水位の高低による塩分分布の数値計算結果を 示寸. 陸域地下水位(distance $x=0 \mathrm{~m}$ ) 老低い場合 (図-8(a)) から高い場合 (図-8(c)) へと変化させると, 低塩分を示 寸濃い青色の最も沖側の部分が，陸域地下水位が高くな るに従いより沖側に約 $50 \mathrm{~m}$ 進行し, 低塩分の部分がよ り広がっていることがわかる。このことから，陸域地下 水位の高低が干潟域における塩分分布に影響を及ぼして おり，陸域地下水位が高い場合では，より広範囲にわた り塩分の上昇を妨げていることが示唆された．なお，地 下水位 $1.6 \mathrm{~m}$ とは, 被圧が存在する場合に対応する.

図-9 は地下水位 $1.1 \mathrm{~m}$ における計算開始後 60 日目以 降の 1 周期分の水平流速分布を示している. 水平流速が 沖向きあるいは岸向きの範囲が潮汐の影響により変化し ている. 図-10 は地下水位 $1.1 \mathrm{~m}$ における計算開始後 60 日目以降の 1 周期分の鉛直流速分布を示したものである. この図から, 満潮汀線付近（距離 $600 \mathrm{~m}$ 付近）において 鈆直上向きの湧出が常時発生し，その沖側にこれを補償 するような弱い鉛直下向きの浸透流が発生していること が分かった. $200 \mathrm{~m}$ より沖側では密度流の効果によりわ ずかに表層の水平流速が沖向きに小さく, 底層の水平流 速が大きい鉛直分布になっている，ただし，計算領域全 体で比較すると岸-沖での水平流速の違いに比べて鉛直 

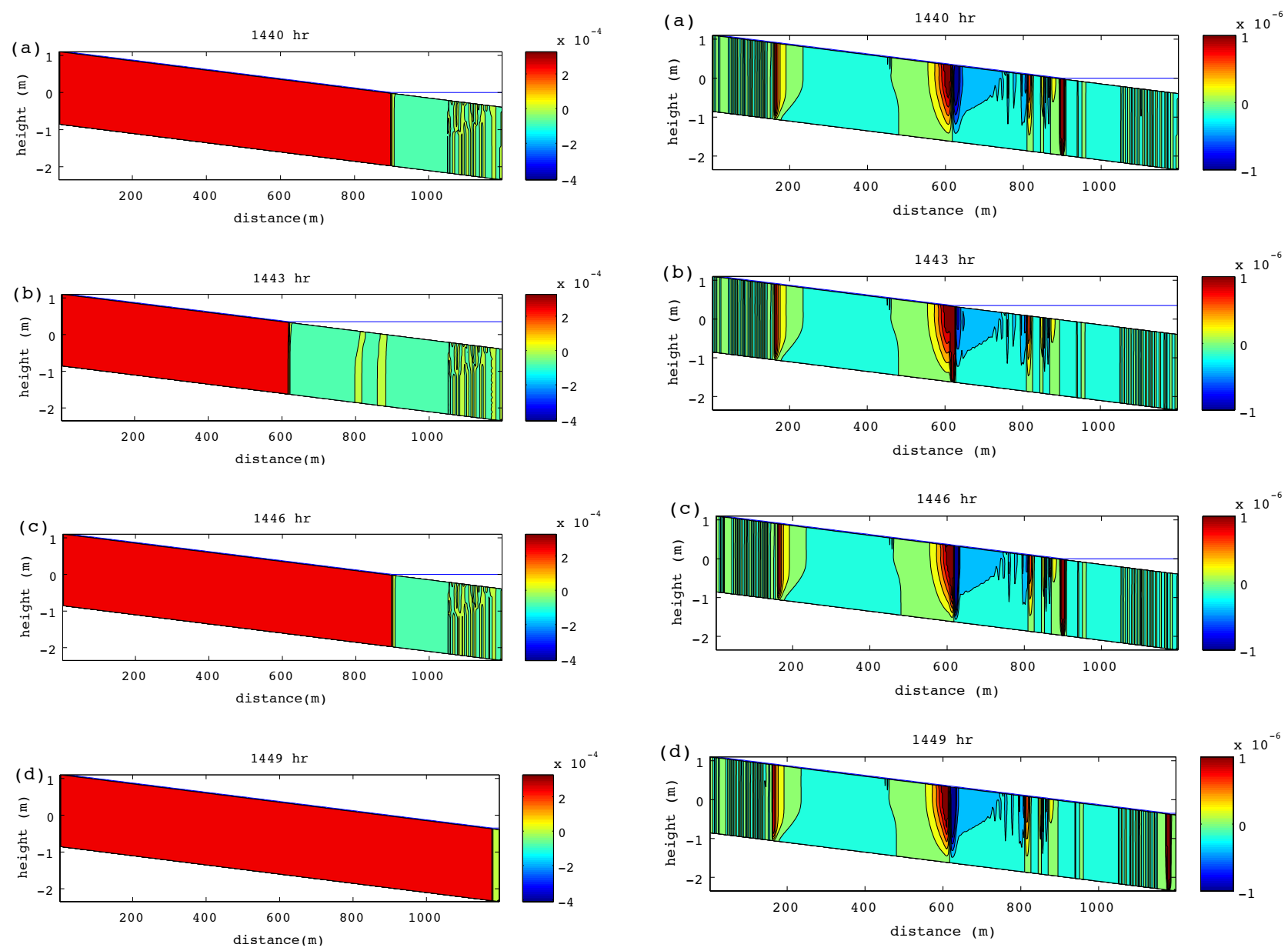

図-9 地下水位 $1.1 \mathrm{~m}$ における計算開始後 60 日目以降の 1 周期 分の水平流速分布. (a)平均流速 (上げ潮), (b)満潮時, (c)平均潮位 (下げ潮), (d) 干潮時

方向の水平流速の差はわずかであり, また, 水平方向に 比べて鉛直方向の計算範囲は薄いことから, 図-9ではそ の違いは判別できず，図-10 でわずかに鉛直流速の等值 線が曲がっているのみである. なお， $600 \mathrm{~m}$ 付近での鉛 直方向の循環流は, 計算上の動水勾配に換算すると十分 に議論できるオーダーの結果であり, 数值誤差の結果か ら発生したものではない，つまり，潮汐によって水底面 で断続的な塩分供給が満潮汀線付近まで達するため，そ の付近に密度界面が形成され，鉛直の循環流が生じたと 考えられる. また，局所的な変化を除き，鉛直流速の分 布には潮汐に伴う大きな分布の変化は見られなかった. 鉛直の循環流の位置は密度界面の位置と関係があると考 えられる.つまり, 水底面からの断続的な塩分供給によ って塩水のフロントが満潮汀線付近まで進行寸るが，満 潮汀線より岸側への塩分供給には限界があり, 潮汐の変 化に対する干潟地中の浸透流の応答は遅いため, 次第に 密度界面の位置は平衡状態に達し, 鉛直流の位置も変動 しなくなると考えられる.このことから，満潮汀線付近 では湖水の干潟表層への浸透よりも地中からの湧出が干 潟表層の水質を支配していると考えられる.

図-10 地下水位 $1.1 \mathrm{~m}$ における計算開始後 60 日目以降の 1 周期分 の鉛直流速分布．(a)平均潮位（上げ潮)，(b)満潮時，(c) 平均潮位 (下げ潮), (d)干潮時

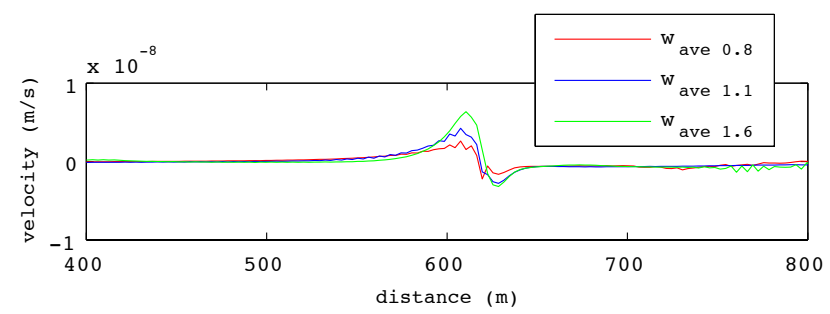

図-11 地下水位 $0.8,1.1$, および $1.6 \mathrm{~m}$ における満潮汀線付近での 干潟面近傍の60潮汐分の鉛直流速の平均值

図-11 は地下水位 $0.8,1.1$, および $1.6 \mathrm{~m}$ での満潮汀線 付近での干潟面近傍の鉛直流速の 60 潮汐分の平均值を 示したものである．地下水位が高くなるに従い，干潟面 方向への湧出が最大 3 倍程度大きくなっていることが分 かる．これは，既往の研究 ${ }^{14)} て ゙$ 観測されている融雪期で の満潮汀線付近の湧出速度の増大と陸上土壌由来のフル ボ酸様物質の蛍光強度の増加に一致する結果であるとい える. 


\section{4. おわりに}

本研究の結論を以下に示す.

1) 現地観測結果より, 塩分, 密度の約半日周期の変動 は，潮汐による第一湖内部まで入り込んできた海水 の影響を受けたものと考えられ，地中においても潮 汐による影響を少なからず受けていると考えられた。

2) 陸側の地下水位(St. 1) と干潟(St. 2)における水位の測 定結果から，融雪期においては相対的に陸側の地下 水位が高く，それ以外の時期に比べてわずかに干潟 域で低塩分化している。

3）既往の研究 ${ }^{14)}$ と同様に，融雪期に干潟域で涌出傾向 が強くなる結果が得られた. 数值解析の結果と合わ せて考察した結果，融雪期において陸側の地下水位 が比較的高いことが地下水湧出と干潟水質の低塩分 化の要因になっていることが明らかになった。春季 において干潟域付近の塩分が低く保たれることで低 塩分帯に生息する水生生物が生息できる環境が生ま れ，これらを餌とする多くの鳥類が春季にこの干潟 域付近で観測される要因となっていることが示唆さ れた。

\section{参考文献}

1) 環境省 : モニタリングサイト 1000 シギ・チドリ類調査春 季速報，環境省自然環境局生物多様性センター，65p, 2010.

2）環境省：モニタリングサイト 1000 シギ・チドリ類調査春 季速報，環境省自然環境局生物多様性センター，65p，
2011.

3）環境省 : モニタリングサイト 1000 シギ・チドリ類調査春 季速報, 環境省自然環境局生物多様性センター, $65 \mathrm{p}$, 2012.

4) 環 境省: 閉鎖性海域ネット, www.env.go.jp/water/heisa/heisa_net/waters/komukeko.html

5) 日本野鳥の会 : 翼が結ぶ重要生息地ネットワーク, www.wbsj.org/nature/hogo/others/iba/search/sites/hokkaido/7-k omukeko.html

6) 独立行政法人国立環境研究所 : 干潟の大切さを考える, www.nies.go.jp/kanko/kankyogi/45/10-11.html

7) 栗原 康 : 干潟は生きている, 岩波書店, (1980), $219 \mathrm{p}$.

8) 細川恭史 : 浅海域での生物による水質浄化作用, 沿岸海洋 研究ノート, Vol.29, No.1, (1991), pp.28-36.

9) 海の自然再生ワーキンググループ : 海の自然再生ハンド ブックーその計画・技術・実践一，第 2 巻干潟編, 2004.

10）独立行政法人国立環境研究所 : 干潟・浅海域の保全をめ ぐって, www.nies.go.jp/kanko/kankyogi/03/12-13.html

11）丸谷靖幸，中山恵介，駒井克昭，渡辺謙太，三好英一，一 見和彦, 桑江朝比呂, コムケ湖における現地観測結果を用 いた湖内の流動特性に関する基礎的検討, 土木学会論文 集 B3（海洋開発）, Vol.69, No.4,pp.1201-1206, 2013.

12）吉江祐人，丸谷靖幸，中山恵介, 駒井克昭, 新谷哲也, 渡 辺謙太, 一見和彦, 桑江朝比呂, コムケ湖における水質及 び流動特性の解明，土木学会論文集 B3 (海洋開発), Vol.70, No.4, pp.1185-1190, 2014.

13) Kuwae T., Miyoshi, E., Hosokawa, S., Ichimi, K., Hosoya, J., Amano, T., Moriya, T., Kondoh, M., Ydenberg, R. C. and Elner, R. W. : Variable and complex food web structures revealed by exploring missing tropic links between birds and bilfilm, Ecology Letters, 15, pp.347-356, 2012,

14）駒井克昭, 中山恵介, 松原健也, 川口貴之, 山崎新太郎, 渡辺謙太，一見和彦，桑江朝比呂，コムケ湖における干潟 水質の分析・変動特性に関する検討，土木学会論文集 B3 （海洋開発）,Vol.70, No.2,pp.1191-1196, 2014.

\section{INFLUENCE OF INFILTRATION FLOW ACCOMPANIED BY SNOWMELT ON WATER QUALITY IN TIDALFLATS IN LAKE KOMUKE}

\section{Tomohiko TAKEUCHI, Katsuaki KOMAI, Keisuke NAKAYAMA, Kenta WATANABE, Kazuhiko ICHIMI, Yukinobu SATO and Tomohiro KUWAE}

In Lake Komuke, located in the northeast of Hokkaido, salinity and water level, and groundwater level of the vicinity of tidal flats were observed in the tidal flat in the snowmelt season to summer, and numerical analysis of the infiltration flow accompanied by snowmelt. In field observation results, water level in terrestrial groundwater level and tidal flats, landward groundwater level was higher in the snowmelt season than the other season. From further results of numerical analysis, the salinity in tidal flat was forced not to increase widely in the case of high landward groundwater level than in the case of low landward groundwater level. Moreover, up-welling was slightly strong in the case of high groundwater level, and made sediment salinity lower. The aquatic organisms can live in low salinity zone kept in the tidal flat in the spring season. It is the evidence that the many birds feeding these aquatic organisms in the spring season are frequently observed. 